\title{
Some Insights Into Financial Literacy Among Undergraduate Students: A Case of Bosnia and Herzegovina
}

\author{
Jasmina Okicic $^{1}$, Meldina Kokorovic Jukan ${ }^{1} \&$ Mensur Heric ${ }^{1}$ \\ ${ }^{1}$ Faculty of Economics, University of Tuzla, Bosnia and Herzegovina \\ Correspondence: Jasmina Okicic, Faculty of Economics, University of Tuzla, Bosnia and Herzegovina.
}

Received: September 28, 2020

Accepted: November 4, 2020

Online Published: January 20, 2021

doi:10.5430/ijfr.v12n3p103

URL: https://doi.org/10.5430/ijfr.v12n3p103

\begin{abstract}
The purpose of this research is to provide some insights into financial literacy among undergraduate students focusing primarily on the relationship between financial knowledge, financial attitudes and financial behavior and on possible gender and financial education gap in financial literacy. Using the purposive sampling technique, data collection was carried out from April to June 2020, yielding a sample of 1,046 valid responses. To gain a better understanding of the relationship between financial behaviour, financial attitudes and financial knowledge, we, primarily, use exploratory factor analysis and multiple regression model. The research findings have revealed several important issues. First, findings have suggested that financial knowledge, financial attitudes and gender may be considered as an antecedent of the financial behaviour of undergraduate students. Second, findings have also suggested a statistically - significant difference between the financial literacy of undergraduate students concerning their exposure to formal financial education.
\end{abstract}

Keywords: financial literacy, gender, financial education

\section{Introduction}

Consumers living in a complex financial environment need financial literacy to improve financial decision making (Atkinson \& Messy, 2012; Huston, 2010). Generally speaking, to achieve financial well-being, financial literacy has played a fundamental role in encouraging young women and men to make responsible decisions. In that respect, financial literacy has been recognized as an essential life skill (OECD, 2017). Individuals with a low level of financial literacy exhibit overconfidence, risk-loving and impatience-financial behaviour that is recognized as a major cause of the financial crisis (Mudzingiri, Mwamba, \& Keyser, 2018). That being said, the low level of financial literacy might harm individuals and nations. More complicated environments require individuals to be more knowledgeable about different aspects of life such as health, technology, finance etc. The concept of financial literacy is very complex. In this regard, as pointed out by Aren and Dinç Aydemir (2014), researchers study the concept of financial literacy from different angles. Academicians use financial literacy to explain economic wellbeing, financial decisions and behaviour, but they rarely deal with two important issues, such as governance and social well-being.

It is probably true to say that extensive research of empirical and theoretical dimensions of financial literacy among the general population has already been conducted. However, most of these studies typically concentrate on developed countries. In that respect, the authors selected the subject of this paper on the ground that not many relevant publications with a focus on the financial literacy of young women and men in countries dealing with the transitional economy can be found in the current literature.

Therefore, and based on the above-identified research gap, the purpose of this research is to provide some insights into financial literacy among undergraduate students focusing primarily on the relationship between financial knowledge, financial attitudes and financial behavior and on possible gender and financial education gap in financial literacy.

Key research objectives are as follows:

RO1. To determine the relationship between financial knowledge, financial attitudes and financial behaviour.

$\mathrm{RO} 2$. To investigate a possible gender gap in financial literacy among undergraduate students. 
RO3. To examine a difference in financial literacy of undergraduate students concerning their exposure to formal financial education.

The paper is intended to produce valuable pieces of information from a policy perspective that may be beneficial to government decision-makers in the process of designing unique financial education initiatives targeted for young people and aimed at increasing their financial literacy. The paper is organized as follows. Following the introduction, part two offers a summary of the literature review that is important to the paper's main objective. Part three discusses the methods of data and analysis. The core of the paper is part four which involves review and discussion of initial empirical findings. Some final remarks and conclusions are found in the last chapter.

\section{Literature Review and Hypothesis Development}

The initial results of financial literacy were reported by Lusardi and Mitchell (2009) and Lusardi (2008a, 2008b, 2012a, 2012b). Financial literacy has varying definitions and approaches because this concept has been loosely used (Remund, 2010). Warmath and Zimmerman (2019) argue that financial literacy encompasses three domains of knowledge, namely financial skill, self-efficacy and explicit knowledge. Zait and Bertea (2014) view the concept of financial literacy as a combination of five dimensions: financial knowledge, financial communication, financial ability, financial behaviour and financial confidence. In this study, we will use the definition given by the OECD INFE (2011) and Atkinson and Messy (2012), where financial literacy is defined as a combination of awareness, knowledge, skill, attitude and behaviour necessary to make sound financial decisions and ultimately achieve individual financial wellbeing. This definition is the starting point of a financial literacy measurement tool consisting of financial knowledge, behavior and attitude (Atkinson \& Messy, 2012).

\subsection{Financial Knowledge, Financial Attitudes and Financial Behaviour}

According to OECD (2013), the most significant dimension of financial literacy is financial behaviour. This is also acknowledged by Setyawati and Suroso (2016) who claim that behaviour is essential and the most important element of financial literacy. Similar, financial attitude is usually outlined as a factor which motivates the behavior of an individual (Moore, 2003). Finally, and as suggested by Lusardi and Mitchell (2014), financial knowledge is measured through a few questions that measure key financial concepts. Similar, Atkinson and Messy (2012) state that financial knowledge encompasses knowledge about key financial concepts whereas the way individual behaves significantly impacts on financial wellbeing. The authors view attitudes and preferences as factors that have direction role regarding behaviour. According to Cucinelli, Trivellato and Zenga (2019) individuals may show different financial attitudes and financial knowledge as a result of regional, social and economic characteristics. Evidence of the effect of financial knowledge and attitude on financial behaviour can be found in the recent literature (Atkinson \& Messy (2012), Potrich, Vieira, \& Mendes-Da-Silva (2016), Felipe, Ceribeli, \& Lana (2017), Hayhoe et al. (2005), Amagir, Wilschut \& Groot (2018) etc.).

Following the previous discussion, we propose the following hypotheses:

H1a: Financial knowledge influences the financial behaviour of undergraduate students.

H1b: Financial attitudes of undergraduate students influence their financial behaviour.

\subsection{Gender and Financial Literacy}

Many recent studies (Erner, Goede-Menke, \& Oberste (2016), Tavares, Almeida, \& Cunha (2019), Garg \& Singh (2018), Lusardi, Mitchell, \& Curto (2010), Chen \& Volpe (1998), Bucher-Koenen et al. (2014), Fonseca et al. (2012), Yu, Wu, Chan, \& Chou (2015), Khurshed \& Iftikhar (2014), Okičić \& Kakeš (2019), Falahati \& Paim (2011), Greimel-Fuhrmann \& Silgoner (2018), Oseifuah, Gyekye, \& Formadi (2018), Kiliyanni \& Sivaraman (2018), Agnew, Maras, \& Moon (2018), Barboza, Smith, \& Pesek (2016), Hasler \& Lusardi (2017), etc. have shown that there is a potential gender gap in terms of financial literacy. Following that, we propose the following hypothesis:

H2: Gender may be considered as an antecedent of the financial literacy of undergraduate students.

\subsection{Education and Financial Literacy}

As pointed out by Fabris and Luburić (2016) many recent studies have shown the importance of financial education. However, recent literature has shown rather ambiguous results when it comes to the effect of financial education on financial literacy. For example, while Mandell and Schmid Klein (2009), Fernandes, Lynch Jr. and Netemeyer (2014), Farinella, Bland and Franco (2017), West (2012), etc., raised some doubts about the long-term effectiveness of financial literacy courses, Wagner (2019), Carlin and Robinson (2012), Pavković, Anđelinović and Mišević (2018), Oppong-Boakye and Kansanba (2013), Barboza, Smith and Pesek (2016), Kadoya and Khan (2020) found a positive relationship between financial education and financial literacy. Hanson and Olson (2018) argue that family talks 
about financial issues produce valued financial knowledge and may be an important factor in designing a financial literacy program. Based on a systematic literature review Amagir et al. (2018) have found evidence shows that school-based financial-education programs can improve children's and adolescents' financial knowledge and attitudes.

Therefore, following the recent findings, we propose the following hypothesis:

H3: There is a difference in the financial literacy of undergraduate students concerning their exposure to formal financial education.

\section{Data and Methodology}

\subsection{Data Source and Sample}

Using the purposive sampling technique, data collection was carried out from April to June 2020, yielding a sample of 1,046 valid responses from students enrolled in undergraduate programs at one of the following eight public universities in Bosnia and Herzegovina: University of Tuzla, University of Sarajevo, University of Zenica, University of Banja Luka, University of Bihać, University of Mostar, University Džemal Bijedić of Mostar and University of East Sarajevo.

Table 1. Overview of basic characteristics of the sample

\begin{tabular}{cccc}
\hline & Characteristic & Frequency & Per cent \\
\hline Gender & Male & 322 & 30.8 \\
Exposure to formal & Female & 724 & 69.2 \\
financial education & Yes & 130 & 12.4 \\
& No & 916 & 87.6 \\
Field of science and technology (Note & Natural sciences & 3 & .3 \\
1 1) & Engineering and technology & 253 & 24.3 \\
& Medical and health sciences & 279 & 26.7 \\
& Agricultural sciences & 14 & 1.3 \\
& Social sciences & 431 & 41.3 \\
Year of study & Humanities & 63 & 6.0 \\
& $1^{\text {st }}$ & 247 & 23.6 \\
& $2^{\text {nd }}$ & 230 & 22.0 \\
Current residence & $3^{\text {rd }}$ & 245 & 23.4 \\
& $4^{\text {th }}$ & 265 & 25.3 \\
Living environment & $5^{\text {th }}$ & 48 & 4.6 \\
& $6^{\text {th }}$ & 11 & 1.1 \\
& Federation of Bosnia and Herzegovina & 602 & 57.6 \\
& Republika Srpska & 433 & 41.4 \\
\hline Srčko distrikt & 11 & 1.1 \\
& Urban & 701 & 67.0 \\
& Rural & 345 & 33.0 \\
\hline
\end{tabular}

Source: Authors' work

The data collection instrument is a structured questionnaire with closed questions, divided into several sections. The first section addresses the financial attitudes, financial behaviour and financial knowledge, whereas the second section considers specific socio-economic characteristics of the respondents.

\subsection{Variables}

The concept of financial literacy is measured by financial knowledge, financial behaviour and financial attitude. The 
questionnaire was primarily based on the $\operatorname{OECD}(2018)$, Atkinson and Messy $(2011,2012)$ and Lusardi and Mitchell (2011).

To determine the level of financial knowledge, two groups of questions were created. The first group refers to basic financial knowledge and it consists of seven questions related to financial exchange rates, interest on a loan and the time value of money. The second group refers to advanced knowledge and it consists of six questions that measure the knowledge of simple and compound interest, inflation and risk diversification.

As suggested by Potrich, Vieira and Mendes-Da-Silva (2016), each correct answer from the first group of questions was awarded a score of 1.0. Similar, each correct answer related to the second group of questions was given a score of 2.0. Table 2 contains an overview of the basic parameters of descriptive statistics for the financial knowledge score.

Table 2. Descriptive statistics for the financial knowledge score

\begin{tabular}{ccccc}
\hline Financial knowledge score & Obs. & Mean & $\begin{array}{c}\text { Standard } \\
\text { deviation }\end{array}$ & $\begin{array}{c}\text { Maximum achievable } \\
\text { financial knowledge score }\end{array}$ \\
\hline Basic & 1,046 & 4.10 & 1.14 & 7 \\
Advance & 1,046 & 6.08 & 2.62 & 12 \\
\hline
\end{tabular}

Source: Authors' work

When it comes to basic financial knowledge, $56.41 \%$ of respondents did not know that it is less likely that they will lose all of their money if they save it in more than one place. Most of the respondents (55.16\%) did not know the practical meaning of the EUR/USD quotation. Surprisingly, 52.87\% of the respondents did not know that in their homeland, i.e. Bosnia and Herzegovina, stock exchange even exists. Speaking of another group of financial knowledge questions, $94.17 \%$ of the respondents did not give a correct answer in case of compound interest and $69.02 \%$ of respondents do not understand the relationship between inflation and interest rates. Similar findings are reported by Babajić, Okičić and Kokorović Jukan (2018). On the other hand, most of the respondents gave the correct answer in case of simple interest (75.72\%), risk diversification (51.82\%).

Table 3 shows all variables used in each scale, with the respective means, and standard deviations.

Table 3. Scales used, variables, means and standard deviations

\begin{tabular}{llcc}
\hline Code & \multicolumn{1}{c}{ Item } & Mean & $\begin{array}{c}\text { Standard } \\
\text { deviation }\end{array}$ \\
\hline FA1 & I think that a person needs to live for today, not for tomorrow. & 2.26 & 1.16 \\
FA2 & I think I need to do my best so my family could have a better life someday. & 4.73 & .59 \\
FA3 & I find spending money more satisfying than long-term savings.* & 2.98 & 1.14 \\
FA4 & Money is there to be spent.* & 3.46 & 1.10 \\
FA5 & I tend to live for today and let tomorrow take care of itself.* & 1.85 & 1.04 \\
FA6 & I am willing to risk my money. * & 2.36 & 1.21 \\
FB1 & I am saving money. & 3.65 & 1.17 \\
FB2 & I stick to a weekly and monthly budget & 3.99 & 1.00 \\
FB3 & Before I buy something I carefully consider whether I can afford it. & 4.40 & .82 \\
FB4 & I pay my bills on time. & 4.58 & .73 \\
FB5 & I pay close attention to my financial situation. & 4.39 & .82 \\
FB6 & I set long term financial goals and strive to achieve them. & 3.72 & 1.15 \\
FB7 & At least to some extent, I try to make a purchase decision based on quality and & 4.04 & .86 \\
& independent information. & 1.92 & 1.37 \\
\hline
\end{tabular}

Note: * - reverse coded item

Source: Authors' work 
The data in the previous table present the used latent variables, their codes, items, as well as the results of the mean and standard deviation. When observing financial attitude, the highest mean was registered for the FA2. When it comes to financial behaviour, the highest mean was registered for the FB4.

\subsection{Methods}

Besides independent samples t-test, we primarily use exploratory factor analysis and, based on the similar research of Potrich, Vieira and Mendes-Da-Silva (2016) and Hayhoe et al. (2005) following multiple regression model:

$$
F B=a+b_{1} F K S+b_{2} F A+b_{3} G e n+b_{4} E d u
$$

In the previous model, FB is the notation for financial behaviour; FKS refers to financial knowledge score; FA refers to financial attitude; Gen is a dummy variable ( $\mathrm{D}=1$ for female students, 0 otherwise), Edu is a dummy variable (D $=1$ for being exposed to formal financial education, 0 otherwise).

\subsection{Empirical Results}

\subsubsection{Independent Samples T-Test}

In respect to our second and third hypothesis, we performed an independent samples t-test to examine possible gender and education gap when it comes to all three dimensions of financial literacy. First, we examined the possible gender gap when it comes to financial knowledge. Based on the results of independent t-test, evidence of a statistically significant difference between the financial knowledge score and gender $(\mathrm{t}(667.968)=-6.749, \mathrm{p}=.000)$ has been found. Particular gender gap is present when it comes to questions related to simple interest $(\mathrm{t}(878.377)=$ -7.980, $\mathrm{p}=.000)$, compound interest $(\mathrm{t}(958.359)=3.727, \mathrm{p}=.000)$, inflation $(\mathrm{t}(573.647)=-3.253, \mathrm{p}=.000)$, financial exchange rates $(\mathrm{t}(609.811)=-2.237, \mathrm{p}=.000)$ and risk diversification $(\mathrm{t}(636.878)=-5.289, \mathrm{p}=.000)$. Next, we examined the possible gender gap when it comes to financial attitudes. Based on the results of independent t-test, a statistically significant difference between the financial attitude score and gender $(\mathrm{t}(1042)=-.943, \mathrm{p}=.346)$ has not been confirmed. Finally, possible gender gap when it comes to financial behaviour is investigated. Based on the results of independent $t$-test, evidence of a statistically significant difference between the financial behaviour score and gender $(\mathrm{t}(1042)=2.015, \mathrm{p}=.044)$ has been found. Particular gender gap is present when it comes to sticking to weekly and monthly budget $(\mathrm{t}(1042)=3.983, \mathrm{p}=.000)$, paying bills on time $(\mathrm{t}(479.123)=4.709, \mathrm{p}=.000)$, and keeping a close personal watch on financial affairs $(\mathrm{t}(1042)=2.906 \mathrm{p}=.004)$.

In respect to our third hypothesis, a possible formal financial education gap when it comes to financial literacy is investigated. Based on the results of independent t-test, evidence of a statistically significant difference between the exposure to formal financial education and financial knowledge $(\mathrm{t}(178.726)=-6.668, \mathrm{p}=.000)$, financial attitude $(\mathrm{t}(1042)=-3.407, \mathrm{p}=.001)$, and financial behavior $(\mathrm{t}(1042)=-3.824, \mathrm{p}=.041)$.

Presented results are generalised in the following table.

Table 4. Identified gap

\begin{tabular}{cccc}
\hline Factor & Financial knowledge & Financial attitudes & Financial behaviour \\
\hline Gender & $*$ & $*$ & $*$ \\
Formal financial education & $*$ & $*$ & $*$ \\
\hline
\end{tabular}

Note: $*$ gap exists based on the independent samples t-test

Source: Authors' work

\subsubsection{Results of Exploratory Factor Analysis}

The exploratory factor analysis was performed on variables related to financial behaviour and financial attitudes using principal component analysis (Varimax rotation). Financial knowledge was not included in the exploratory factor analysis because it is measured as a score. Initially, the factorability of the 15 items, presented in Table 3 , was examined. In that respect, we used a few well-known criteria. Firstly, a statistically significant correlation between 14 of the 15 items was found, suggesting a reasonable factorability. Finally, the communalities for two items, FA2 and FB8, were very low and that is why these items were excluded from further analysis. The results show two factors accounting for $45.11 \%$ of the variance. The Kaiser-Meyer-Olkin sampling adequacy measure is .807 , which is higher than the usually recommended value of .6. The.Bartlett's test of sphericity was significant $(\chi 2(45)=3150.70$, $\mathrm{p}<.05)$. Based on the items, these factors can be considered as financial attitudes and financial behaviour. Table 5 
shows the factor analysis results.

Table 5. EFA results

\begin{tabular}{lll} 
& \multicolumn{3}{c}{ Rotated Component Matrix $^{a}$} \\
\cline { 2 - 4 } FB5 & Component & Financial attitudes \\
Financial behaviour & .780 & \\
FB2 & .675 & \\
FB6 & .666 & .623 \\
FB3 & .623 & .731 \\
FB7 & .600 & .716 \\
FB1 & .568 & .659 \\
FB4 & .504 & .743 \\
FA5 & & \\
FA4 & & \\
FA1 & &
\end{tabular}

Extraction Method: Principal Component Analysis. Rotation Method: Varimax with Kaiser Normalization.

a. Rotation converged in 3 iterations.

Source: Authors' work

Next, we tested the internal consistency of the identified factors (Table 6).

Table 6. Scale statistics

\begin{tabular}{lccccc}
\hline Measure & $\mathrm{N}$ & Number of items & Mean & Standard deviation & Cronbach's Alpha \\
\hline Financial attitude & 1,046 & 4 & 13.44 & 3.30 & .730 \\
Financial behaviour & 1,046 & 7 & 28.78 & 4.27 & .763 \\
\hline
\end{tabular}

Source: Authors' work

Cronbach's Alpha measures reliability in the range of 0 to 1 , where a value of 0.60 to 0.70 is considered the lower limit of acceptability (Hair, Black, Babin, \& Anderson, 2014). Having that in mind, it may be concluded that both scales, financial behaviour and financial attitude, had an acceptable level of reliability.

\subsubsection{Multiple Linear Regression Model}

Before running a multiple linear regression model, we examined the correlation between financial knowledge, financial attitudes and financial behaviour. Results of the Pearson correlation indicated that there was a small, but significant, positive association between financial attitudes and financial behaviour, $(\mathrm{r}=.483, \mathrm{p}=.000)$ and between financial knowledge and financial behaviour, $(\mathrm{r}=.129, \mathrm{p}=.000)$.

Following assumptions regarding outliers, data collinearity, independent errors, random normal error distribution, homoscedasticity and data linearity, and non-zero variances, prior estimation of a multiple linear regression model were investigated:

- Outlier analysis was based on the analysis of standard residuals and it indicated that two respondents needed to be removed. After that, the same procedure was carried out once again, which showed that the data contained no outliers (Std. Residual Min = -3.253, Std. Residual Max = 3.188).

- When it comes to multicollinearity, tests have shown that it was not problematic in this case. (FKS, 
Tolerance $=.916, \mathrm{VIF}=1.091 ; \mathrm{FA}$, Tolerance $=.982, \mathrm{VIF}=1.018 ;$ Gen, Tolerance $=.951, \mathrm{VIF}=1.051 ;$ Edu, Tolerance $=.949, \mathrm{VIF}=1.054$ ).

- The assumption of independent errors was not violated (Durbin-Watson value $=1.99$ ).

- The histogram of standardized residuals (Figure 1) showed that the data contained errors that were roughly normally distributed. The same goes for the normal P-P plot of standardized residuals (Figure 2), which showed points not entirely on the line, but similar to each other.

- The assumptions of homogeneity of variance and linearity were not violated (Figure 3).

- The assumption of non-zero variances was not violeted (Financial knowledge, Variance $=9.49$; Financial attitudes, Variance $=10.92$; Financial behaviour, Variance $=17.86$ ).

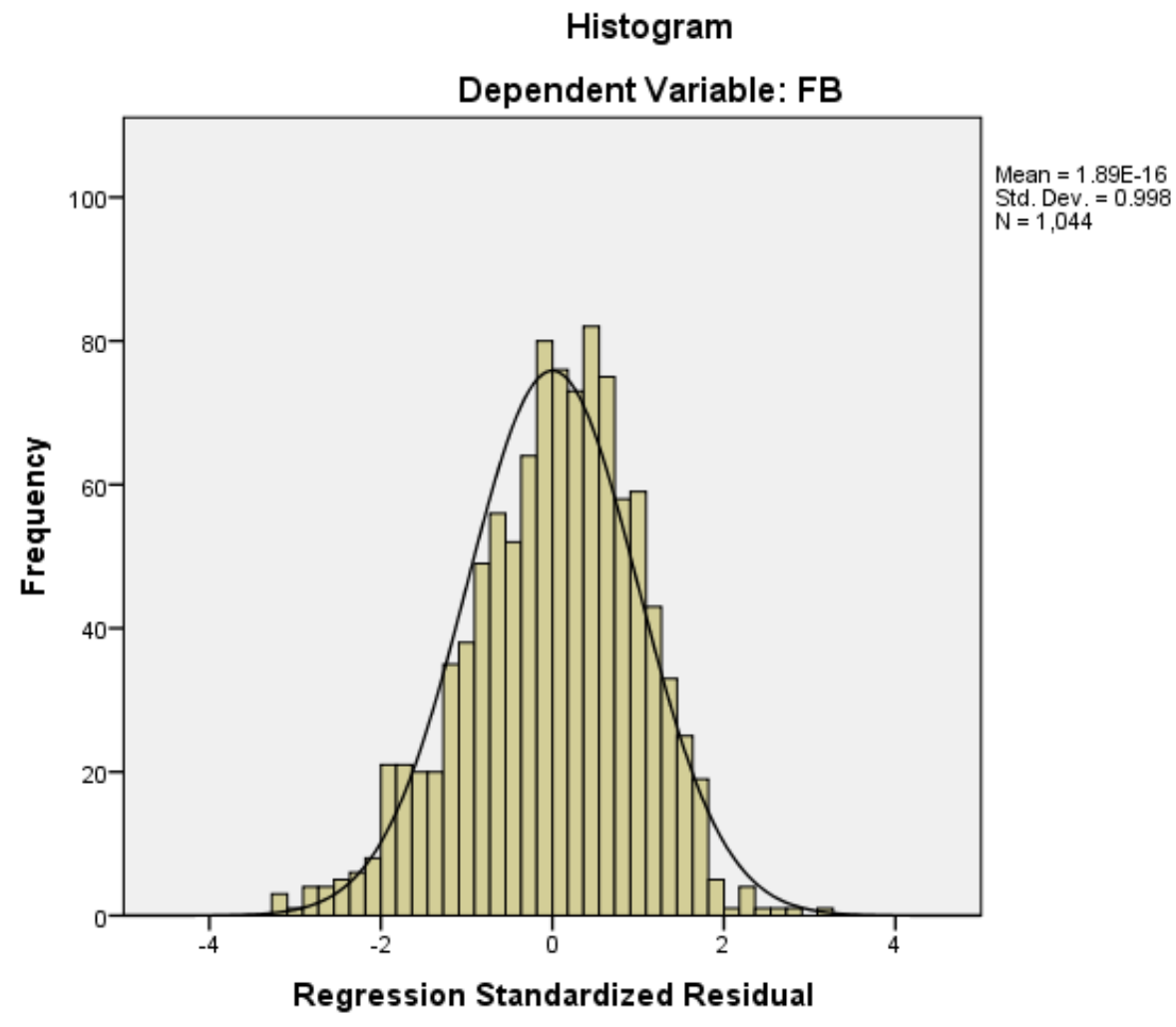

Figure 1. Histogram

Source: Authors' work 


\section{Normal P-P Plot of Regression Standardized Residual}

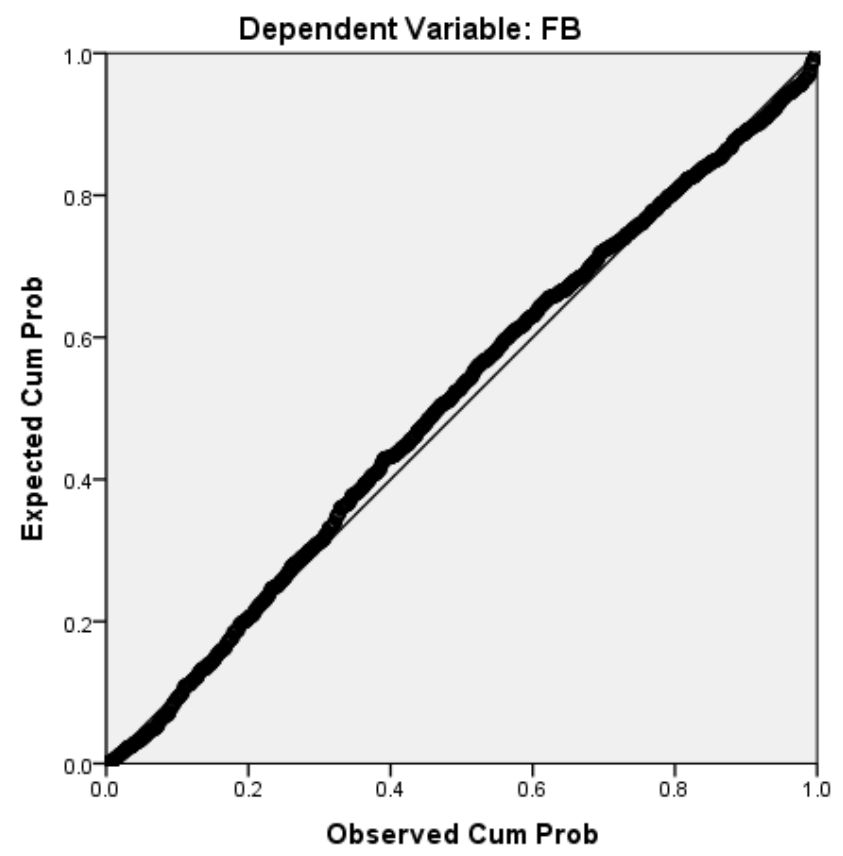

Figure 2. Normal P-P plot

Source: Authors' work

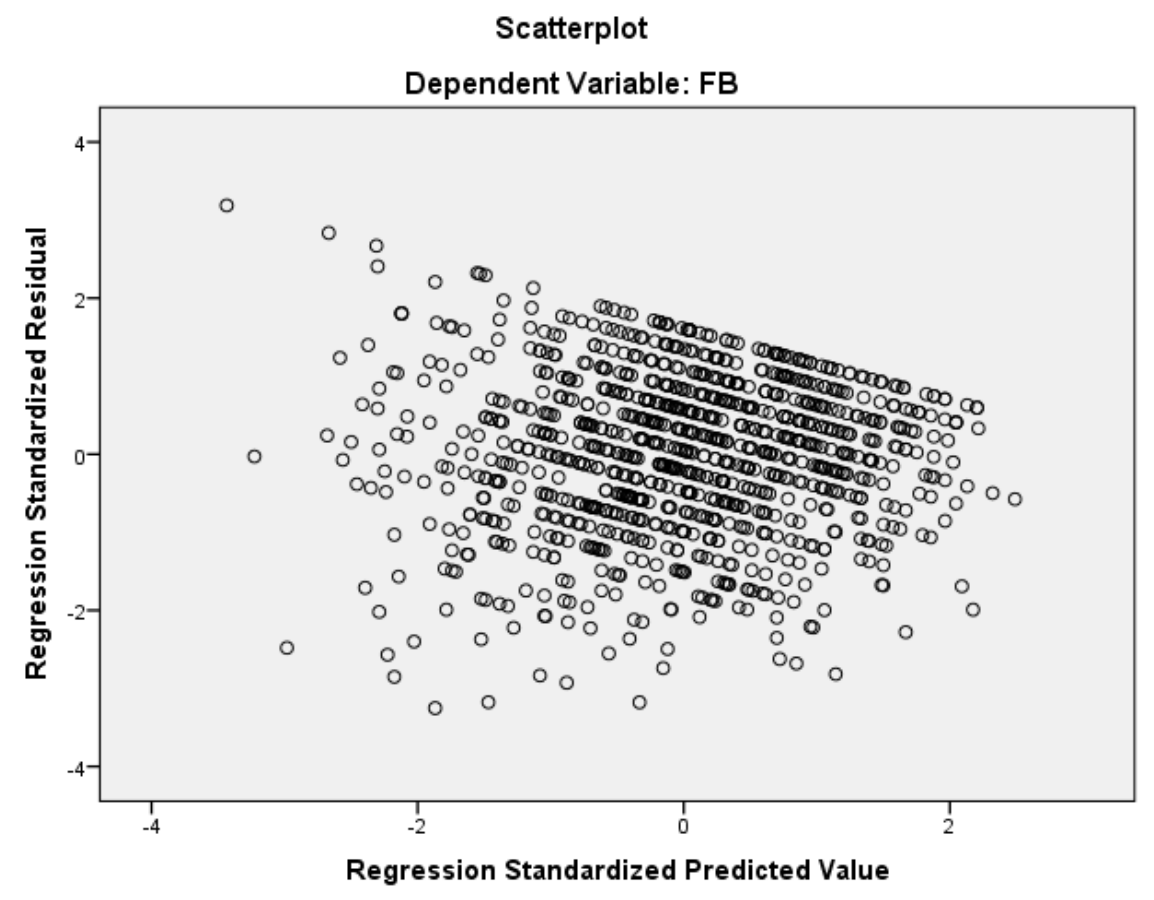

Figure 3. Scatterplot

Source: Authors' work 
Multiple regression was conducted to see if financial knowledge, financial attitudes, gender and exposure to formal financial education predicted financial behavior. Selected independent variables explain a certain amount of the variance in the financial behaviour $(\mathrm{F}(4,1039)=55.09, \mathrm{p}<.001, \mathrm{R} 2=.175$, Adjusted $\mathrm{R} 2=.172)$.

The individual predictors were examined further and indicated that financial knowledge (Beta $=.108, \mathrm{p}=.000$ ), financial attitudes (Beta $=.378, \mathrm{p}=.000)$, gender $(\mathrm{Beta}=.092, \mathrm{p}=.002)$, were significant predictors in the model. At the significance level of $5 \%$, that was not the case when it comes to exposure financial education (Beta $=.053, p$ $=.070)$.

\section{Discussion}

Based on the presented results the following can be concluded:

- Financial knowledge and financial attitudes of undergraduate students have a positive impact on their financial behaviour. These findings are following the findings of Potrich, Vieira and Mendes-Da-Silva (2016) who found the same evidence among undergraduate students in southern Brazil. When it comes to the impact of financial knowledge and financial attitudes on the financial behaviour of undergraduate students, similar results have been reported by Felipe, Ceribeli and Lana (2017) who found a positive effect only of financial attitude on the financial behaviour of an individual. However, the impact of financial knowledge was not statistically significant in this case.

- Gender may be considered as an antecedent of the financial literacy of undergraduate students. This is mainly in accordance with the findings of Erner, Goede-Menke and Oberste (2016), Tavares, Almeida and Cunha (2019), Garg and Singh (2018), Lusardi, Mitchell and Curto (2010), Chen and Volpe (1998), Bucher-Koenen et al. (2014), Fonseca et al. (2012), Yu, Wu, Chan and Chou (2015), Falahati and Paim (2011), Khurshed and Iftikhar (2014), Okičić and Kakeš (2019), Falahati and Paim (2011), Greimel-Fuhrmann and Silgoner (2018), etc.

- In terms of exposure to formal financial education, there is a possible education gap when it comes to all three dimensions of financial literacy. This statement is mainly in accordance with the results of Wagner (2019), Carlin and Robinson (2012), Oppong-Boakye and Kansanba (2013) and, particularly, Pavković, Anđelinović and Mišević (2018) who have found a significant difference in financial literacy between students concerning their exposure to financial education.

\subsection{Policy Implications}

As it was mentioned earlier in the paper, financial literacy has assumed a fundamental role in enabling young women and men to make responsible decisions to attain financial wellbeing. Financial literacy contributes to improving financial wellbeing, which consequently, improve the quality of life.

Different approaches to introduce financial education can be utilized. When it comes to structuring financial educational programs and positioning them within the educational system on all levels (primary, secondary or higher education) it is not clear which type of financial education programs and on which level of education will yield long term benefits for individuals when they are faced with a different type of financial decisions (i.e. retirement planning, investing in a new home, buying a car, taking a student loan, etc.) during their life cycle.

Lusardi et al. (2010) find that it may be beneficial to provide financial education before individuals start to make decisions that may influence their financial position, while other research (Fernandes et al., 2014) argues that just-in-time approach has more effect on financial decision making. Having this said and in the light of obtained results on financial literacy level among the student population in Bosnia and Herzegovina, it can be argued that formal education at university level contributes to a higher level of financial literacy. In terms of policy relevance, policymakers' efforts should be directed to introduce mandatory finance courses throughout all universities and, even consider curricular reforms towards introducing financial courses in secondary education.

It would be also important to promote other initiatives in terms of non-formal financial courses with emphasis that "one-size-fits-all" programs are unlikely to be effective (Lusardi et al., 2010). This leads to the conclusion that due attention is needed for tailoring financial education programs respecting the specific needs of different groups of young people, especially because the gender gap was found in this particular research.

\section{Conclusion}

In Bosnia and Herzegovina, little attention has been paid to financial literacy in general and, particularly, when it comes to undergraduate students. Based on this research gap, the purpose of this paper was to provide some insights into financial literacy among undergraduate students focusing primarily on the relationship between financial 
knowledge, financial attitudes and financial behavior and on possible gender and financial education gap in financial literacy. The research findings have revealed the following important issues: (1) Financial knowledge and financial attitudes of undergraduate students have a positive impact on their financial behaviour; (2) Gender may be considered as an antecedent of financial literacy of undergraduate students; and (3) In terms of exposure to formal financial education, there is a possible education gap when it comes to all three dimensions of financial literacy.

From the policy perspective, policymakers' efforts should be directed to introduce mandatory finance courses throughout all universities and, even consider curricular reforms towards introducing financial courses in secondary education. Furthermore, having in mind other relevant more global research, it would be of great significance to promote other initiatives in terms of non-formal financial courses with emphasis that "one-size-fits-all" programs are unlikely to be effective, leading to the conclusion that due attention is needed for tailoring financial education programs respecting specific needs of different groups of young people, especially because gender gap was found in this particular research.

In terms of developing tailor-made and gender-sensitive financial literacy initiatives, this study is expected to lead to the more effective creation of evidence-informed policy decision making in Bosnia and Herzegovina. Further research should consider a greater and more representative sample of young women and men from Bosnia and Herzegovina that would lead to a creation of appropriate financial literacy index.

\section{Acknowledgements}

The research reported in this publication was supported by the Federal Ministry of Education and Science, Bosnia and Herzegovina.

\section{References}

Agnew, S., Maras, P., \& Moon, A. (2018). Gender differences in financial socialization in the home-An exploratory study. International Journal of Consumer Studies, 42(3), 275-282.

Amagir, A., Groot, W., Maassen van den Brink, H., \& Wilschut, A. (2018). A review of financial-literacy education programs for children and adolescents. Citizenship, Social and Economics Education. 17(1), 56-80. https://doi.org/10.1177/2047173417719555

Amagir, A., Wilschut, A., \& Groot, W. (2018). The relation between financial knowledge, attitudes towards money, financial self-efficacy, and financial behavior among high school students in the Netherlands. Empirische Pädagogik, 32(3/4), 387-400.

Aren, S., \& Dinç Aydemir, S. (2014). A Literature Review on Financial Literacy. Finansal Araştırmalar ve Çalışmalar Dergisi, 6(11), 3-49.

Atkinson, A., \& Messy, F. (2012). Measuring Financial Literacy: Results of the OECD/International Network on Financial Education (INFE) Pilot Study. OECD Working Papers on Finance, Insurance and Private Pensions, No. 15. Paris: OECD Publishing. https://doi.org/10.1787/5k9csfs90fr4-en

Babajić, A., Okičić, J., \& Kokorović Jukan, M. (2018). Identification of Barriers to Financial Inclusion among Youth. International Business Research, 11(7), 120-129. https://doi.org/10.5539/ibr.v11n7p120

Barboza, G., Smith, C., \& Pesek, J. G. (2016). Assessing financial literacy, gender gap and cognitive differences. Journal of Financial Education. 42(3-4), 205-242.

Bucher-Koenen, T., Lusardi, A., Alessie, R., \& van Rooij, M. (2014). How Financially Literate are Women? An Overview and New Insights. NBER Working Paper No. 20793. Retrieved January 31, 2019, from https://www.nber.org/papers/w20793.pdf

Carlin, B. I., \& Robinson, D. T. (2012). What does financial literacy training teach us?. The journal of economic education, 43(3), 235-247. https://doi.org/10.1080/00220485.2012.686385

Chen, H., \& Volpe, R. P. (1998). An analysis of personal financial literacy among college students. Financial Services Review, 7(2), 107-128. https://doi.org/10.1016/S1057-0810(99)80006-7

Cucinelli, D., Trivellato, P., \& Zenga, M. (2019). Financial literacy: The role of the local context. Journal of Consumer Affairs, 53(4), 1874-1919. https://doi.org/10.1111/joca.12270

Erner, C., Goedde-Menke, M., \& Oberste, M. (2016). Financial literacy of high school students: Evidence from Germany. The Journal of Economic Education, 47(2), 95-105. https://doi.org/10.1080/00220485.2016.1146102

Fabris, N., \& Luburić, R. (2016). Financial education of children and youth. Journal of Central Banking Theory and 
Practice, 5(2), 65-79.

Falahati, L., \& Paim, L. Hj. (2011). Gender Differences in Financial Literacy among College Students. Journal of American Science, 7(6), 1180-1183.

Farinella, J., Bland, J., \& Franco, J. (2017). The Impact of Financial Education on Financial Literacy and Spending Habits. International Journal of Business, Accounting, \& Finance, 11(1), 1-12.

Felipe, I. J. dos S., Ceribeli, H. B., \& Lana, T. Q. (2017). Investigating the Level of Financial Literacy of University Students. Revista de Administração, Contabilidade e Economia - RACE, 16(3), 845-866. https://doi.org/10.18593/race.v16i3.13458

Fernandes, D., Lynch Jr, J. G., \& Netemeyer, R. G. (2014). Financial literacy, financial education, and downstream financial behaviors. Management Science, 60(8), 1861-1883. https://doi.org/10.1287/mnsc.2013.1849

Fonseca, R., Mullen, K. J., Zamarro, G., \& Zissimopoulos, J. (2012). What Explains the Gender Gap in Financial Literacy? The Role of Household Decision Making. The Journal of Consumer Affairs, 46(1), 90-106.

Garg, N., \& Singh, S. (2018). Financial literacy among youth. International Journal of Social Economics, 45(1), 173-186. https://doi.org/10.1108/IJSE-11-2016-0303

Greimel-Fuhrmann, B., \& Silgoner, M. (2018). Analyzing the Gender Gap in Financial Literacy. International Journal for Infonomics, 11(3), 1779-1787.

Hair, J. F., Black, W. C., Babin, B. J., \& Anderson, R. E. (2014). Multivariate Data Analysis. Harlow-Essex: Pearson Education Limited.

Hanson, T. A., \& Olson, P. M. (2018). Financial literacy and family communication patterns. Journal of Behavioral and Experimental Finance, 19, 64-71. https://doi.org/10.1016/j.jbef.2018.05.001

Hasler, A., \& Lusardi, A. (2017). The Gender Gap in Fnancial Literacy: A Global Perspective. Washington: Global Financial Literacy Excellence Center, The George Washington University School of Business.

Hayhoe, C. R., Leach, L., Allen, M. W., \& Edwards, R. (2005). Credit cards held by college students. Journal of Financial Counseling and Planning, 16(1), 1-10.

Huston, S. J. (2010). Measuring financial literacy. Journal of Consumer Affairs. 44(2), 296-316. https://doi.org/10.1111/j.1745-6606.2010.01170.x

Kadoya, Y., \& Khan, M. S. R. (2020). Financial Literacy in Japan: New Evidence Using Financial Knowledge, Behavior, and Attitude. Sustainability, 12(9), 3683. https://doi.org/10.3390/su12093683

Khurshed, I., \& Iftikhar, A. (2014). Gender Disparities in Financial Literacy among University Level Students. City University Research Journal, 4(2), 202-207.

Lusardi, A. (2008a). Financial literacy: an essential tool for informed consumer choice?. NBER Working Paper No. 14084. Retrieved March 5, 2019, from https://www.nber.org/papers/w14084.pdf

Lusardi, A. (2008b). Household Saving Behavior: The Role of Financial Literacy, Information, and Financial Education Programs. NBER Working Paper No. 13824. Retrieved March 15, 2019, from https://www.nber.org/papers/w13824.pdf

Lusardi, A. (2012a). Financial Literacy and Financial Decision-Making in Older Adults. Generations, 36, 25-32.

Lusardi, A. (2012b). Numeracy, Financial Literacy, and Financial Decision-Making. Numeracy, 5(1), 1-12.

Lusardi, A., \& Mitchell, O. S. (2009). How ordinary consumers make complex economic decisions: financial literacy and retirement readiness. NBER Working Paper No. 15350. Retrieved March 5, 2019, from https://www.nber.org/papers/w15350.pdf

Lusardi, A., \& Mitchell, O. S. (2011). Financial literacy around the world: an overview. Journal of Pension Economics and Finance, 10(4), 497-508.

Lusardi, A., \& Mitchell, O. S. (2014). The Economic Importance of Financial Literacy: Theory and Evidence. Journal of Economic Literature, 52(1), 5-44. https://doi.org/10.1257/jel.52.1.5

Lusardi, A., Mitchell, O. S., \& Curto, V. (2010). Financial literacy among the young. Journal of Consumer Affairs, 44(2), 358-380. https://doi.org/10.1111/j.1745-6606.2010.01173.x

Mandell, L., \& Klein, L. S. (2009). The impact of financial literacy education on subsequent financial behavior. 
Journal of Financial Counseling and Planning, 20(1), 15-24.

Moore, D. L. (2003). Survey of financial literacy in Washington State: Knowledge, behavior, attitudes, and experiences. Social and Economic Sciences Research Center Technical Report Number 03-39 Washington State Department of Financial Institutions.

Mudzingiri, C., Mwamba, J. W. M., \& Keyser, J. N. (2018). Financial behavior, confidence, risk preferences and financial literacy of university students. Cogent Economics \& Finance, 6(1), 2-25. https://doi.org/10.1080/23322039.2018.1512366

OECD. (2013). Financial Literacy and Inclusion: Results of OECD/INFE Survey Across Countries and By Gender. $\begin{array}{llll}\text { Retrieved September } & 30, & 2020, & \text { from }\end{array}$ https://www.oecd.org/daf/fin/financial-education/TrustFund2013_OECD_INFE_Fin_Lit_and_Incl_SurveyResul ts_by_Country_and_Gender.pdf

OECD. (2017). G20/OECD INFE report on adult financial literacy in G20 countries. Retrieved July 31, 2020, from http://www.oecd.org/finance/G20-OECD-INFE-report-adult-financial-literacy-in-G20-countries.pdf

OECD. (2018). OECD/INFE Toolkit for Measuring Financial Literacy and Financial Inclusion. Retrieved July 31, 2020, from http://www.oecd.org/financial/education/2018-INFE-FinLit-Measurement-Toolkit.pdf

OECD INFE. (2011). Measuring Financial Literacy: Core Questionnaire in Measuring Financial Literacy: Questionnaire and Guidance Notes for conducting an Internationally Comparable Survey of Financial literacy. Paris: OECD.

OECD/OCDE. (2007). Revised Field of Science and Technology (FOS) Classification in the Frascati Manual. Retrieved July 18, 2020, from https://unstats.un.org/unsd/EconStatKB/KnowledgebaseArticle10269.aspx

Okičić, J., \& Kakeš, D. (2019). Insights into Gender Differences in Financial Literacy of Youth. In Leko Šimić, M., \& Crnković, B. (Eds.), Conference Proceedings - 8th International Scientific Symposium Economy of Eastern Croatia - Vision and Growth (pp. 474-484). Osijek: Faculty of Economics in Osijek, J.J. Strossmayer University of Osijek.

Oppong-Boakye, P. K., \& Kansanba, R. (2013). An assessment of financial literacy levels among undergraduate business students in Ghana. Research Journal of Finance and Accounting, 4(8), 36-49.

Oseifuah, E., Gyekye, A., \& Formadi, F. (2018). Financial literacy among undergraduate students: empirical evidence from Ghana. Academy of Accounting and Financial Studies Journal, 22(6), 1-17.

Pavković, A., Anđelinović, M., \& Mišević, D. (2018). Measuring financial literacy of university students. Croatian Operational Research Review, 9(1), 87-97.

Potrich, A. C. G., Vieira, K. M., \& Mendes-Da-Silva, W. (2016). Development of a financial literacy model for university students. Management Research Review, 39(3), 356-376. https://doi.org/10.1108/MRR-06-2014-0143

Remund, D. L. (2010). Financial literacy explicated: The case for a clearer definition in an increasingly complex economy. Journal of Consumer Affairs, 44(2), 276-295. https://doi.org/10.1111/j.1745-6606.2010.01169.x

Setyawati, I., \& Suroso, S. (2016). Sharia Financial Literacy and Effect on Social Eco 7 nomic Factors (Survey On Lecturer In Indonesia). International Journal of Technology Enhancements and Emerging Engineering Research, 5(2), 92-106.

Tavares, F. O., Almeida, L. G., \& Cunha, M. N. (2019). Financial Literacy: Study of a University Students Sample. International Journal of Environmental and Science Education, 14(9), 499-510.

Wagner, J. (2019). Financial education and financial literacy by income and education groups. Journal of Financial Counselling and Planning, 30(1), 132-141. https://doi.org/10.1891/1052-3073.30.1.132

Warmath, D., \& Zimmerman, D. (2019). Financial Literacy as More than Knowledge: The Development of a Formative Scale through the Lens of Bloom's Domains of Knowledge. Journal of Consumer Affairs, 53(4), 1602-1629. https://doi.org/10.1111/joca.12286

West, J. (2012). Financial literacy education and behaviour unhinged: combating bias and poor product design. International Journal of Consumer Studies, 36(5), 523-530. https://doi.org/10.1111/j.1470-6431.2012.01118.x

Yu, K. M., Wu, A. M., Chan, W. S., \& Chou, K. L. (2015). Gender Differences in Financial Literacy among Hong Kong Workers. Educational Gerontology, 41, 315-326. https://doi.org/10.1080/03601277.2014.966548 
Zait, A., \& Bertea, P. E. (2015). Financial literacy-Conceptual definition and proposed approach for a measurement instrument. The Journal of Accounting and Management, 4(3), 37-42.

\section{Note}

Note 1. This classification is based on the Revised Field of Science and Technology (FOS) Classification in the Frascati Manual. For more information see OECD/OCDE (2007).

\section{Copyrights}

Copyright for this article is retained by the author(s), with first publication rights granted to the journal.

This is an open-access article distributed under the terms and conditions of the Creative Commons Attribution license (http://creativecommons.org/licenses/by/4.0/). 